\title{
Neural Coding and Synaptic Transmission: Participation Exercises for Introductory Psychology
}

\author{
Richard Reardon \\ Francis T. Durso \\ Donald A. Wilson \\ University of Oklahoma
}

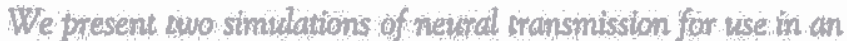
Introductory Psychology class: These strublacions ithistrate the complex cading properties of a single nevrom, especially how excit-

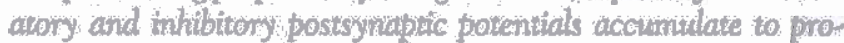
dure an action potential A follow-up exercise, issing the fromeworke of the simple children's gane Musical Chains, illustrates synoptic transmission including the effects of psychoactive druss at the synapse.
\end{abstract}

Introductory Psychology students typically report that the material on phosiological psychology is troublesome to mister Part of the problem may be instructors diffieuly in inparting an appreciation of the functioning of one neuron and how that neuron cominunicates with several other neurons.

There ate few exereises that belp students visualize and assinilate the fundamentals of neuroscience. Ackil (1986) described a rivia typeibord game using physíological tents and concepts. This game may be helpful in motivating stodents to study, but it is not really a demonstration and thus does not pernit students any expetience of the workings of the neuroni Hanilton and Knox (1985) described a simula. thon of the thajor structures of the inervous system. This simulation captures the operatton of the nervous systemat a molar level; however, it does not helpexplain functioning at the theuronil level. Kasschau (1981) offered a sitaple and effective, but linited, demonstration of neuronal functioning, depicting the relative difference in speed between an action potential and syriaptic thanismission.

We report herein two additional exercises that involve students in a series of simulations of neuronal processes. The first exercise fllustifates how excitatory and inhibitory postsynaptic potentials accumulate to ptoduce an action potential. The second exercise, a followelup to the first, illuistrates chemical transmission at the synapse.

\section{Neural Coding Exercise}

Students simulate how the neuron accumulates and decodes inputs to produce an action potential. This exercise demonstrates spatial and temporal summation of graded excitatory and inhilbitory postsynaptic potentials, the importance of firitig rate, the all-or-none nature of the action potential, and the refractory period. In addition, scudents cangain an appreciation of the complexity of even the stuallest neural netwokk and begin to understand how noise tin the system and perturbations at the neuronal level need not affect the output from a hightier ordet system. We introduce the exercise soon after neural functioning has been ptesented in a regulat class session.

We use the exercise in discussion sections $(10$ to 25 students), although it could also be performed in classes of 30 to 45. Some students" ability to view the proceedings may be restricted in classes larget than 45 . The minirnum time re quired is 8 to 10 min. The only materials needed are seven index cards; six cards have the letter $E$ in one color ink, and the severth card has an $I$ in a contrasting colot. We have found that the followting sequetace of four cases is optimal.

\section{The Basic Simutation (Excitation Only)}

One studentacts as the receiving neuron and is stationed at the blackbond facing the class, Six other students, preferably in the front tow of the class, represent six input paths. (These students are referred to as infusts) The instructor gives each an E index cand, thus all inputs in the basic sitrulationare excitatory, Fich of the inputs is instructed to. hold up ihis or her card for $3 \mathrm{~s}$, wirh a 5 -s interval berween card flaskes (i.e., each trial lasts.8 s; the instructor should stagger the statting times for each of the inputs by about 1 to 2.). The receiving neuron fires whenevet any three cards are visible at the same time; that is, the neuron reaches a firing threshold whenever three cards are simultanieously pres sented. To: represent firing, the receiving neuron tutns around and writes "I fire" on the blackboard. This turning away from the thiputs mirtors a refractory period, during which time the neuron cannot respond to inputs. The te: ceiving neiton is told to ignoreacard that is in the process of going up or dow and the inpuss are instructed to make theit cand presentations ertisp. After 1 or $\mathbf{2}$ min, the instructor endls the simulation, and the class counts the number of times the receiving neuron fired.

\section{Excitation and Inhibition}

The second simulation illustrates what happens when inhibition is added. A seventh student with the I card joins the inputs of the basic simulation. Whenever the receiving neurom sees the I card, he or she must iguore one of the E cards that might be sisible at the same time. Thus, the receiving 
Meuron woutd not fre if thee Es and one I wete witible at the same noment. Howeve, if wotuld fire iffour Es were present at the same time as the L. The decregse infintug rate should be quite noticeable.

\section{Temporal Summation}

Temboril summation refers to the ablitw of the neuron to make decisions about its own firing trate based oa the rates of the incoming input signals. For this simutation, six inputs areall excitatory. Fue of the inputs flash their ciris for 3 sat 5-s intervals, as in the basic simalaton. The sixti input Flashes for 3 s witha 3 in interval between signals (each tilil is $6 \mathrm{~s}$ for this input). The armease fin fing rate over that of the basic simulation is folly dramatic.

\section{Spatial Summation}

Spatid summation of maded tostsyaptic porentids refers oco the neuton's tendency to add together inputs: ariving at diferent locations Becuse graded potentials decrease in

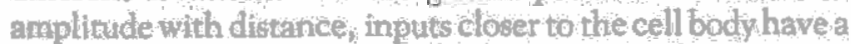
greater fect on the recelving inew that those farther away To simulate this, fout of the six inputs are in the frent of the classoom, and the remaning two are the teat of the room, semarated by several students. (fotherwise, this sim alation is the same as the basc simulation lin terims of ingto signal dumbion and atorial.) The students shotd notio how mud more diffeud it is to detect he inputs in the rutar of the room compared to those in the front. The ferwon will occasionally miss one of these imputs, thus fattug to reach threshold, resulting in afiring rite that is islower than that of the basic sitnulation.

Astime permits, the instructar may leadthe class through addicional more complex stmuladons. For example. tin

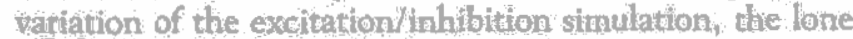
mhibitory intut could be shown to have an even greater thibitory effect by incteasing its input rate. $O_{t}$ a lone in hibizory input in the back of the tooti can be shown to bave very litule effect on the firing rate of the recerving neuron

\section{Effectivents of the Exercise}

To gauge the impact of this extictie on our sudents, we selected eight discusston sections from a single semester of fering of our lange lituoductory Psychology sourse. Two instructors were involved; both were expertenced graduatestudents. who were responsible for four sectioms exch. Each instructor supervised the simulations in twa of their discis: ston sections and deliwerted lecture of about 25 thinon the action potential and neural coding to the other two sections. The lectures were generated fron the instructor's manual of the text used for the course. One week tater the studenits in all eight sections who were present the pirvious week were given an s-ltem, multiple-choiee quir on neusophysiology. These itens were taken from the same item pool used in actul exams, but they did not duplicate items from the exams given that semester. Four of the items assessed general knowledge about the functions and parts of the neuron and

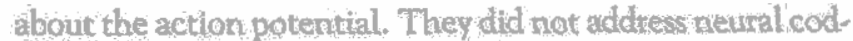
ing. The vemaining four trens did attenpt to tap studentst? understanding of excitation/inhibinom, temporal summeton, spatal sumation, and firing tates.

The exercise groups petomed betwet than the lecture groupson thee of the four items that dealt with coding The percentage correat for eah moup (exencisendid lectuthe, respectivel y) for each 1tem was Item 1, 32\% and 26\% Item 2, $68 \%$ and $73 \%$, Lten $3,80 \%$ and $63 \%$ and Item $4.7 \%$ and 60\%. The overall pereentages of correct items for eachgroup were 63 for the exereise group and 55 for the lecture group. The total correct scores for the four items were analyzed with an unpaired two gtoup test Theexercise groups $(\mathrm{M}:=2.51$ or 63\%) performed better than the lectutegroups $(\mathrm{M}=2.21$ or $55 \%), t(19)=1,60, p<06$ one tailed Differences bewem the exerciseand lecture gtoups could have been due to variables other than the exexcise-lecture manipulation (e. the lecture group) Therefore, we also performed at test on the diffetences between the excercise and leoture groups on the items that wete untelated to coding. On the fout such itemis the mean contect seore was 1.80 for the exercise groups and 1,87 for the lecture groups, not a stgificant difference, $(119)=36$. one-tailed. The data suggest that the exercise prodices an effect that is at least so good as a leoture on treural coding (ima wat that is probabl thote fun than a lecture).

\section{Synaptic Transinistion Follow Up Exercise}

Once students have a grasp of noural coding, we simulate spaptie transinisson, In this exerctse, which models the familiar chiddren's game Musical Chairs, students wale the role of wathus drugs and newrotransmitrers. "They simulate the action of the nurodhenicds at the reaser sites of the ariniating axon and at the receptor sites of the receiving denatife Differences among drugs that blodk reuptalke, oc cupy receptor sites, and mimic the netrotransmitter can be illustrated ensily

\section{Basic Simulation}

Place fout chais in the front of the class to represent origin sites of the releasing gxon, and an equal number of char facing them to represent the receptor sites on the tecelving dendrite, la the basic simulation, students representing neurrotransitters sit in the axon chairs and on a slgnal from the inistructor attempt to occupy the teceptor chairs they must oft completely in the receptor chalis and then atcenpt to return to the axon chairs (reuptake). The "students reniin seated excent during the short time when they are movin between the two sifes. In the basic simulaiton, attemsts to occupy chatis witl be siccessful, however, In later simulations, the presence of drugs might prevent or factlitate the occupation of either the receptor or releaset site. When all of the receptor chats are occupied by a neurouminmitcen "or a substance that mimics a neurotransmitter, the neuren reaches its firing threshold.

In the basic simulation, the student experiences several basic fearres of synaptic transmission: (a) the origin of neu. 
tounanimitten in the sending neurom, (b) the release of neurotransmitters into the symatic gap, (c) the stimulation of teceptor sites by the neuretransmaitters, and (d) the return of the neurotransmitrers to the originating points. This last feature- - reuptake - is often porolly communicated in introductoty texts and lectures. In addition, when other chemicals onter the suimulation, the student can gain an appreciaton of basic neurotransmisslon arid begin to understand how different drugs affect synaptic transmission. This physiologicall spriaglocard helps the instructor explairy both the effects of substance albuse in later chapters that cover drugs and behavior and the effects of antipsyctiotic miedications wher the course tumis toward psychopathology and treatment. Ve offer three examples:

Mimicking the neurotransmitter. The stimulant dinug nicotitie has effects similar to the neurotransmitter acetylcholine. In the simulation, four students representing the drug nicotine and four stidents representing the neutotransmitter are atvailabte to sit in the receptor chairs. Itittially, students representing the drug can stand behind the axen chairs. At the instructor's signal to melease the neurgtransminter, both the neurotransmitter and the drug students. whill atternpt to occupy the receptor site chairs gilickly filling thein. With reuptake, the neurotransmitter students must thettun to the axon chairs, but the drug students will be present to continue occupaction of the recepro: chaits, that is to conthue stimulation.

- Oceupying receptor sites. The class of medications used to treat schizophrenia have their major effects by occupying the receptor sites that dopamine nonmally occupies. In schizophenics, receptor sites are thought to be too sensitive to doparaine, thus, practical ly speaking, thereits an excess of dopamine in these pattents By blocking the receptor sites

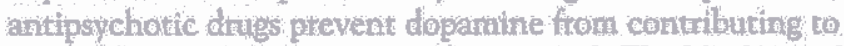
the wnitiation of the postsynaptic potentis. The blocking of dopanine; therefore, tends to relieve psychotie symptoms. In the simulation, at the instructor's signal, 'both the stirdento representing neurotranismitter and those tepresenting antipsychotic datos are teleqsed thto the synaptic gap to sit in the receptor chairs. To distinguish bilocking agents ( $\mathrm{e}_{\mathrm{s}} \mathrm{g}$, hi this simulation) from the mimicking agents ( $\mathrm{eg}$, , as in the previous sitmulation), the blocking agents will begin the exercise behind the receptor chairs instead of behtind the axon chairs. Initially, the advantage will go to the neurotransmit. ter students; but a they retum to the axon chalrs, some receptor chairs will be accupied by the students who repre gent antipsychotic drugs, thus: preventing the netutotrans. mitter students from sitting in a receptor chair following the text releose of neurotrainsmitter. Neurotransmitter stuicents Who do not contact a receptor site because a receptor blocker is sitting in the receptor chilit must seturn, thitough tetuptake to an axton chair to be released again. We usially mention the other raniffication of the dopamine ohenomenon: Antipsychotic medications can bilock tratisumissions tim relared to the pstcheric disturbance, resulting in Parkinson's-1ike symptoms and patients: with Raikinson's disease are often treated with the dopamine precursor, Ludopa.

Blocking retuplake. Sotae äntidepressant drugs prevent the newrotransmitter norepinephime from retuning to the

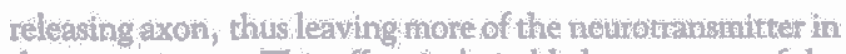
the sroaptic gap. This affece is desirable because one of the biochentcal protilems in psychotic depression is not enough norepinephrine. In the sirnulation, four students tepresenting ontidepressant drug occupy the releasing stte chaitis of norepinephitine after the latter have been released into the gaip. "The four students representing the neurotranstuitter, because they must sit somewhere, will continue to occupy and reoccupy the receptor sites, increasing the neutotransmittet ts impact on the receiving neuton.

Each simulation tikes less than 3 to 4 min. During the first 2 to 3 min, student participants are assigned their roles, the temaining 1 min of so of actual simulation is sufficlent to make the appropriate points. We have found that students participating in the exercise and those observing it are able to remenber which students are neutotrantisintters and which have some other tole - the initial 2 - to 3 minservip, if done carefully, tends to make this clear. However, some anstructors may find it helofiul to have students hold cards that identiffy the roles.

Beyond these basic simulations, the instructor can introduce complexity by combining drugs, placing inert substances into the system, considering the role of enzymatic degradation ( $\mathrm{g} g$, by having some enzyme students "grab" newro, ransmircet sudents, removing them from the synapse), and considering the more complex actiotis of some drugs. Cocante, for example, stimulates the telease of norepinephrine and tinhibitit its reuptake. Amphetamines stim

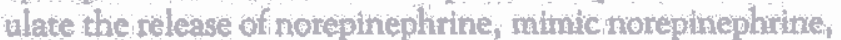
and block teuptake.

\section{Conclusion}

The data we ollected support our impresstons that the neural colling exercise improves student understanding of the complexty of coding. Because the synaptic transmission follow-sip exercise is used optionally, depending on time availability, we have ino formal dato on its effectiveness However, anecolotal reportt from our discussion instructors over several comesters surgest that it helps make conorete the often abstract presentations of synaptic transmission in text. books:

For both exercises, students (and sometimes instructors) often report that ther feel silly playing their roles. We tell them that feeling silly is appropriate and acceptable if an understaiding of neural functionting results.

\section{Refexences}

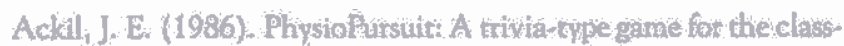
room Texchurg: of sychology 13, 91.

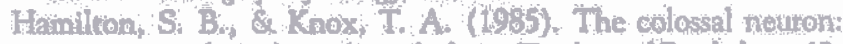
Acting out phystological psychology Teaching of Psycholiogy, 12 . $153-156$.

Kasschau, R. A. (1981). Conduction of a neuronal impulse. In L. T. Benjamin, Jr. \& K. D. Lowman (Eds.), Activities handbook for the teaching of psychology (pp. 207-208). Washington, DC: American Psychological Association. 
Notes

1. We thank Karen Bailey and Nick McDonald for allowing us to use students in their discussion sections to test our exercises and
Temie Thomas for her commenus. Helpfull suggestions by Ruth Aute and the reviewers are also gractefilly alknowledped.

2. Requeste for teprints should be sest to Richard Reardon, De. partment of Psychology, University of Oklahoms, Norman, OK 73019. reardon@oupsy.psy. uolnor.edu.

\title{
Using Feature Films to Teach Social Development
}

\author{
Chris J. Boyatzis \\ California State University, Fullerton
}

\begin{abstract}
To promote understanding of children's social development during middle childhood, students select, view, and analyze a feature film using theory and research from the course. Students write papers analyzing the protagonist's social development, focusing on peer relations and friendship issues. The quality of these papers and student evaluations demonstrate that this assignment is a valuable educational experience. The exercise enriches students' understanding of course content and fosters a more sophisticated perspective on movies about children. Instructors can modify this technique for other developmental topics.
\end{abstract}

Psychology instructors have used feature fillms to foster students' learning (e, g.. Bolt, 1976. Dorris \& Ducey, 1978, Kinney, 1975). More recently, Fleming, Piedmont, and Hiam (1990) discussed the effective use of film ina course on psychiopathology, and Anderson (1992) described the value of film in a course on psychology and law. Thece authors. described many values of film in psychology classes. Students responded positively to the films, perhaps because they of er entertaining, concrete examples of course topics. Students also seemed to become engaged ditectly with film themes, thereby becoming mote involved with counse conteint (Fleming et al., 1990). Filu may also inprove stiudents' critical thinking and perspectives (Anderson, 1.992).

For several years I have used feature films, mostly Eut romean, in an undergraduate course, Middle Childhood, covering development during the elementaty school years. European films were emphasized becalise they capture children's experiences and development note genutinely than do Americar films. The majot purpose of the assigniment was to elucidate social development topics that we studied in the course vita seientific research and theory.

\section{The Film Analysis Assignment}

The timeline for this assignment spans several classes (about 2 weeks) during coverage of social developtnent and peet relations. Sudents complete the assignment during the
Iatter portion of this coverage. During this thime, students continue to learn about sceial development through lecture, readings, and educational films. Sources that I present in class and assign in reading include those by Buhmester and Fuman (1987); Dodge (1983); Hartup (1983) Thorne (1986); and Zarbatany, Hartman, and Rankin (1990).

Students selectafilmifrom alist 1 provide. They watch the movie at home, usually over a weekend, for several reasons. Showing a film in class would require excessive time and Would allow students to watch only one filla for the assign. ment. The take home assigninent allows stidents to watch a film of their own chicice, probably one they had not yet seen. Home viewing also allows the lusury of watching the film or certain scenes mote than once, which could help students better understand how theory and research are exemplified by the eharacter's experience (Avderson, 1992). Although: film rental may pose logistical problems for some students (e:g, those not owning a videocassette tecordec), students. may watch a movie with a elsssmate, sharing the costs and equipment. Students are also encouraged to contact local libraries, which often have varied and inexpensive movie selections.

After watching the movie, students write an essay (of two to (our pages), analyzing some aspects of the film characters" social developtnent. Students are instructed to "use the pisychological theory and rewearch from the course as a framework in which to understand the social development of the chilliren in the movie:" Students are told to "malke connes. tions between the characters and their experiences with ideas we have read or discussed in elass." "Students write their essay in about 1 week and submit it around the time 1 finish the topic.

To facilitate the re analysis; students ate given the follow* ing graestions on a handout: (a) How does the film captute the way a child's peer group thakes up a subculture or "society of children"? How does the child's experience in this societs: differ from his or her experience with adults? (b) How does the film illustrate psychological benefirs of having friends and being in a peer group? Conversely, how does the film

Wi. 21, No. 2, Aprill 1994 